\title{
MAKING DECISIONS IN CRISIS MANAGEMENT IN LÓDŹ VOIVODESHIP
}

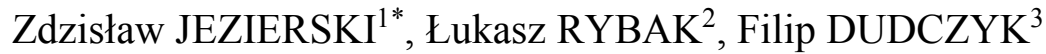 \\ ${ }^{1}$ Institute of Security Sciences, Stefan Batory State University; zdzislawjezierski@wp.pl, \\ ORCID: 0000-0002-2428-7160 \\ ${ }^{2}$ Institute of Computer Science and Technology, Stefan Batory State University; lrybak@pusb.pl, \\ ORCID: 0000-0002-2920-7326 \\ ${ }^{3}$ Student - Linguistics for Business, Philological Faculty, University of Lodz \\ * Correspondence author
}

Purpose: Nowadays, the number of threats for public security is constantly growing. In Poland, the crisis management system was established to counteract them. In the paper, its functioning is shown in the context of the Łódź voivodeship, where in each poviat and commune the crisis management teams work. The main purpose is to identify the stages of the decision making in the crisis management process. The second aim is to show the role of the decision-making body and principles and factors in the decision-making process.

Design/methodology/approach: The paper has been prepared on the basis of reports and opinions of employees of crisis management departments in the region and the source literature. Findings: In a crisis management the decision has an important role. The decision, as a directive, organizes and stimulates the common effort of the people. The quality of the decision depends on the correctness of the decision-making process. This process should be a logical set of ordered operations, which help human to conduct rational analyses and resolve the problems.

Research limitations/implications: The employees of the crisis management departments in the Łódź voivodeship have achieved a high level of management skills, they have developed effective methods and rules for making decisions. To make the decisions in the crisis conditions they prefer the situational approach, which is the result of the systemic approach. As a result, the practical situational directives are created, which means that in a particular situation particular actions, types of motivations, management styles, etc. are applied.

Originality/value: The paper is the first attempt to study this issues in the context of the Lódź region. The paper should be read by managers which interests are focused at the crisis management.

Keywords: safety management, emergency management, crisis management, making decisions.

Category of the paper: Research paper. 


\section{Safety management}

Contemporary definitions describe safety as a sense of peace, certainty and a feeling of security without threats. Dictionaries also indicate that this is a sense of protection against potential dangers. The meaning of this word includes meeting such needs as existence, survival, integrity, identity, independence, peace and certainty of development. This term may refer to a particular entity e.g. a person, a group of people, an office, an institution, a country, a nation, a company, a town, a region etc. Safety is a principal need of both a single human and social groups thus, this is a basic need of a country. Therefore, each human, social group or country strives for influence on its external surrounding as well as its internal zone in a way enabling them to remove threats or at least move them away in order to eliminate fear, concerns and insecurity.

Since ancient times, people have tried to gain control over the environment, introducing different changes in order to make life easier and more comfortable. Much effort has been put to be independent from natural hazards. Such introduced human changes in the natural safe space is called civilization. It is defined by objects, which improve life conditions and control the nature i.e. technology, social life organization, infrastructure etc. Civilization diminishes the number and power of natural hazards, however, at the same time generates new ones, namely, the hazards of civilization. This means that people live and will live in an environment with potential safety threats, which as a result of negative changes in the natural space or civilization space, can change into particular real domain-specific threats e.g. flood, fire, chemical, ecological, or epidemiological threats. These can be caused by natural or man-made disasters and influence life and health of people as well as the condition of their possessions and the natural environment.

The level of overall safety depends on domain-specific safety levels. A particular domainspecific safety level may be gained in many ways - not only by providing particular effectiveness of direct counteractions against ensuing incidents by medical service system. To improve it, following actions can be taken:

- preventing from appearance of a particular safety threats,

- preparing an entity for activation of a particular safety threat in form of an event (education, distribution and availability of preventive measures and forces),

- increasing effectiveness of forces and medical service systems (while counteracting effects of a particular incident),

- action effectiveness of removing consequences of a particular incident.

Therefore, it is possible to shape both domain-specific and overall safety level.

Security situation is not stable and given once for all. In the real world there are constant threats. Not only the nature, but also intentional and unintentional effects of human action may pose a threat. Each entity must, therefore, endeavour to provide itself with stability of security 
situation. In order to do it, an entity security system is being created. It constitutes a number of forces and measures which will provide a sense of personal acceptable safety.

Increasing the level of safety, both domain-specific and overall, is connected with bearing particular costs. Thus, the clear aim should be to achieve maximum safety level with minimum costs.

From the above-mentioned considerations, it can be concluded that there is a possibility of entity safety management both on domain-specific and overall safety level. However, it also needs to be preceded by detailed identification in terms of domain-specific safety threats and their reciprocal correlation, possibilities to decrease probability of their appearance, moderating their course after activation and removing their effects. The acquired knowledge will enable the entity to establish procedures of safety management and create a computer software for support and optimization of its informational and decision-making processes. A safety system for a particular entity should be adjusted to its potential threats and acceptable safety level necessary for a particular entity.

The term safety is closely linked to the term threat, which is its opposite. It has evolved for centuries. In the past threats were generated by the nature and wars. As the progress of human civilization goes on, new threats appear. Their source is human activity. These can be, among many others, of ecological, energetic, economic informational, public, social, information and communication technology and cultural kind. They will appear in the future showing the complexity of the term threat.

In the problem of security management an important thing is to early recognize some symptoms of different threats which may lead to critical situations. A critical situation develops gradually, and certain measures and forces are necessary to solve it. Otherwise, it reaches its apogee in a form of crisis i.e. a situation which poses a threat to basic values, interests and aims of different institutions and social groups. Crisis means loss of control over developing events and no concept how to bring the situation under control. Therefore, it is important to identify threats early and take actions by managing crisis.

\section{Emergency management}

The term emergency management is relatively new, ambiguous and still not precisely defined. However, all attempts to define and present this matter refer to the term management, which appears in management sciences.

The Emergency Management Act specifies that it is the activity of public administration offices that constitutes an element of managing the national security management system, and consists of preventing crisis situations, preparing to take control over them by way of planned activities, responding in case of emergencies, removing their effects and reconstructing 
resources and critical infrastructure (Ustawa z dnia 26 kwietnia 2007 roku o zarządzaniu kryzysowym, 2007).

Many researchers specialized in fields connected with security, by accepting the definition from the above Act, describe in their works special conditions of functioning of an entity which is in charge of emergency management. Such conditions are connected with a hard and full of disruptions system situation, colitogenic relations between different entities mainly of politicalmilitary, socio-economic character, which are in charge of crisis management during a period of natural and man-made disasters.

In National Security Dictionary emergency management is managing a system under pressure in order to solve tense situations. Its task is to prepare for activities aiming at preventing, counteracting and reacting during disruptions of stability of an organization (system) and restoring a normal state of functioning (Balcerowicz, 2008).

On the basis of an analysis of many definitions of this term, it must be stated that emergency management is a classic type of management, but carried out in a specific, unpredictable environment i.e. a crisis situation including its apogee. It is also solving a crisis situation on the basis of the decision taken by public administration offices, and carried out by united contractors when these are not able to solve the problems as a matter of routine activities. Emergency management involves not only reacting to a suddenly appearing crisis situation, but also setting preparatory and preventive measures in order to avoid a potential crisis situation and- if it is necessary - eliminating its results. It concerns providing security in different kinds of crisis situations, in insecure conditions, under pressure, at risk, and moreover, in terms of people, possession, and environment protection,

It is emphasized that the more significance is attached to project implementation at the prevention and preparation stage, the more effective and fast is the solution of a crisis situation at the reaction stage. Solving a crisis situation at this stage means providing coordinated medical service and provision of public order with the use of public services e.g. the fire department and inspections in order to ensure safety and protection of people, possessions and the environment.

The aim of crisis management is minimization of potential threats and efficient activities in case of their appearance. Efficiency means ability to carry out arranged aims, and effectiveness means their level of achievement. Crisis management should also be rational in terms of taken action. The most important goal is to minimize threats to life and health of people as well as their possessions and the environment, therefore reference to financial management is inappropriate. Being rational in terms of crisis management means to use resources in reasonable way (Sienkiewicz-Mały Jurek, Krynojewski, 2010). 


\section{System for making decision in case of crisis management in Łódź voivodeship}

The idea of the Emergency Management Act generally concerns defining the scope of tasks for governing bodies i.e. the Council of Ministers, the Prime Minister, Ministers being in charge of public departments, Directors of the Central Offices, Voivodes, Starosts, Mayors. All these bodies with subordinate safety institutions constitute the crisis management system. The Polish system is a four-level one, i.e. it concerns central, voivodeship, district and commune authorities. It operates on a permanent basis and performs tasks leading to prevention of crisis situations, preparation for loss of control over them due to planned action, and if such has to be taken, efficient reaction and finally, restoring functional balance (Ustawa z dnia 26 kwietnia 2007 roku o zarządzaniu kryzysowym, 2007).

However, the concept of crisis management is based on the primacy of territorial system, where the local authority takes main burden and responsibility for the decision connected with crisis. Particular levels of administrative offices (communes, districts and voivodeships) have different organizations in their resources to take action in a crisis situation i.e. the fire department, the medical service, the public order service (the police, the municipal police) etc. The principle states that in case of a crisis situation, every single action is taken from the lowest administrative unit i.e. communes, districts and voivodeships. In case of insufficient forces and measures, or if a crisis situation spreads throughout a few administrative regions, a higher-level entity takes over the responsibility of solving a particular crisis situation. Voivodeships have the highest level of territorial authority in our country. It must be stated that these have wide prerogatives, which concern especially supervision over services aiming at public safety and responsibility for safety on their areas.

There are also two subsystems in the structure of the emergency management system i.e. managing (making decisions) and executive. This work focuses on the first one in Łódź voivodeship. What needs to be added is the fact that the system for making decisions in crisis management plays an analogous role in the rest of the voivodeships in our country, according to the Emergency Management Act (Sobolewski, 2013).

This Act specifies precisely that superior function in the emergency management system lies with the entity in charge of public administration, which is generally obliged to make decisions, allocate tasks to particular contractors and coordinate action in case of a crisis situation. The management body not only specifies the scope of tasks, but also takes responsibility for taken action in particular stages of crisis management. This subsystem carries out tasks by managing, which is a decision-making process consisting of collecting, gathering and distributing the information. Thus, the management body is a system of ordered elements with following roles: 
- decision-making body - Council of Ministers, Minister of Interior and Administration, voivode, starost, mayor - makes decision on the basis of the act. Therefore, has influence on other entities which carry out their tasks in terms of crisis management;

- advisory body - the Government Team for Crisis Management, a team which works with the Minister of Interior and Administration as well as voivodeship, district and commune teams for crisis management - is opinion-making and advisory body, specifies the strategy of tasks in a particular crisis situation by recommending some solutions, provides communication between a decision-making body and planningcoordination section;

- planning-coordination section - analyses and evaluates information, prepares options of action, suggests ways of dealing with problems and takes responsibility for implementing decisions, task allocation and action coordination.

The second element of crisis management is an executive subsystem, which mainly consists of services such as the fire department, the police, the municipal police, inspections in terms of human resources and technology. These elements form executive entities without which even the most complex decision-making systems and government bodies would not be able to perform any public services according to the law (Pietrek, 2018).

\section{Decision-making principles in crisis management in Lódź voivodeship}

The term decision making in management sciences appeared in the first half of the previous century. In the second half of the $20^{\text {th }}$ century the concept of management decision making evolved and so did new interpretations of this issue. Basic assumptions and statements were presented in some works by Herbert Simon and James March (Simon, March, 1964; Landreth, Colander, 2005). This new field called the decision-making school can be placed among management organization theory, economics, sociology, organizational processes modelling.

In recent years there have been many critical reviews on theoretical approaches to management theory. This theory has been improved due to achievements and practices of the most popular management schools; new views were combined with the old ones concerning establishing, accepting, and realizing management decisions. The theory of decision making still evolves intensively in terms of the theory of management. Managing in crisis situations may be examined from different perspectives, but mainly in terms of subject matter.

Managing in crisis situations is defined by the aim function, which consists of neutralization of phenomena (crises), which are the most dangerous for socio-economic system (organization). Different stages of crisis management lead to either anticipation of coming crisis, diminishing it or getting out of it. Management in crisis situation includes general description of a management process of a socio-economic system, as well as specific 
interactions, which distinguishes crisis from traditional management. Knowledge of the management and decision-making theory is the basis to take conceptual and managerial actions among the employees in Crisis Management Department in Łódź voivodeship Office and crisis managers subordinated to them in districts and communes in this voivodeship.

As a result of over a 10-year work of Crisis Management Department in Łódź voivodeship, the managerial subsystem evolved in terms of organization and human resources at three levels of public administration. The employees in crisis departments in the voivodeship office, starost's offices and commune offices have achieved a high level of managerial skills and worked out effective methods and principles concerning decision making. Although they gained a great experience in crisis management, their aim is to avoid routine activities. Each crisis situation is treated as a new, unrepeatable challenge of its own specifics, which requires a creative approach in order to be solved in a reasonable way, with the use of optimal forces and resources.

The crisis managers in Łódź voivodeship generally have a situational approach to decision making in the time of crisis, which has sprung from the systematic approach. The situational approach is of relativistic nature and is based on the principle 'everything depends'. It does not mean, however, the end of the case. This is the beginning of a search for what exactly it depends on. In this way, situational practical directives appear: in a particular situation (generally concerning the condition of the surrounding) it is desirable to implement a particular action, create particular motivation for people, a particular type of management etc. A decision-maker (manager, director) plays an important role in this concept. The aim of this person is to make a diagnosis of a particular situation and choose the right, appropriate solutions to this situation. There are no ready recipes or schemes, but there are a number of solutions and suggestions advising what to do in different cases, conditions and circumstances. In such terms, crisis management is neither an activity, which can be completely based on the scientific research, models and pre-established programmes (as it can be imagined on the basis of a systematic approach) nor just art. In the situational approach not only the importance of substantial knowledge is emphasized, but also the role of a decision-maker as a diagnostician, a kind of master. Such an approach makes it possible to see crisis management from the angle of systematic categories as the roots of the situational approach are there. It also enables us to move top-down, which is a feature typical of the systematic method (Koźmiński, LatusekJurczak, 2011).

The systematic approach to making decisions in a crisis situation forces decision-makers to define a problem and precisely specify limitations and criteria according to which these entities should evaluate particular decision-making options. Thus, it becomes easier for a lower-level entity to make decisions in similar decision-making cases at a lower level. Also, it is easier for a decision-maker, who solves similar problems many times. 
However, there is also one more important factor in making decisions resulting from complexity of a crisis situation, namely, the art of making decisions due to the fact that it is a creative, individual skill in defining ways to solve problems, finding unconventional ideas and solutions to complicated situations. Art is unique and unrepeatable and that is why it is completely different from science. Therefore, focusing only on the art of making decisions is limited as it provides no regularity and systematicity to problems concerning systematic improvement in decision effectiveness.

Generally, there is no doubt in the conviction that only a scientific approach provides a base to define and solve problems intentionally and improve decision quality and effectiveness in a crisis situation. It needs to be added that a scientific approach does not exclude a decision based on intuition. Art should complement scientific methods, somehow enhance them. Appropriate combination of the use of human logical thinking and intuition altogether with optimization methods and calculation measures significantly increases the probability of making a rational decision (Chyliński, 2015).

In a scientific method, the theory of making decision plays an essential role. This theory should include a system of basic ideas with descriptions of regularities in making decisions, possible methods, methodology of making decisions as well as a list of basic recommendations. This theory supplies decision-makers with a scientifically verified approach to realize basic functions and provides a possibility to improve work effectiveness systematically. The knowledge of the theory how to make decisions is professional competence of each decision-maker (Frankfort-Nachmias, Nachmias, 2001).

This theory is a philosophical category, which means progress of knowledge system, mapping reliably and precisely the matter and regularities of phenomena in a particular area, in the objective reality. Such a system presents guidelines for practical activity. In terms of analogy, the theory of making decisions needs to be understood as a knowledge system, which represents importance of terms phenomenon and decision. Basic directions in the theory of making decisions are objective truth, logical purpose, formal rationality, the ability to develop, basic independence, active influence on practice. What is objective in this theory is checking in practice the adequacy of its laws and principles to express appropriate theoretical assumptions in a subjective way. The essential condition to form theories concerning making decisions as a component of the management theory is to define the subject of the matter, its limitations, directions, forms and methods of testing it (Sułkowski, 2012).

The essence of the process of making decisions among Łódź crisis managers is inner rational base of managerial decisions. The essence of making decisions usually results in different external relations and activities. Basing on this fact, it is necessary to separate the subject study of the decision making theory. The essence of making decisions are activities of a decision-maker due to its elementary managerial functions in the management process. The basic aim of a managerial decision is to provide a coordinating body for a decision-making system. 
In order to achieve these aims, problems connected with a particular situation need to be solved, so specific tasks need to be carried out. The most important of these are: forming a data base; defining limitations and criteria for making decisions; organizing the work of staff. Accepting a decision is a creative, responsible managerial task. It requires defining plans of further activities in accordance with the current condition and depending on a particular managerial area, making structural divisions in the activity system, ordering of co-operation and security measures. A decision is made by a decision-maker who takes full personal responsibility for it. For a decision to be made the managerial staff of a particular office takes part in data preparation.

The process of decision making is reflected in management literature. The systematic analysis provides systematic sciences with a great resource. According to works by scientists specialized in these, the process of decision making, especially for highly hierarchical systems which need to work in crisis situations, has to be divided into two stages, namely, solving a problem and decision making. Furthermore, in the first one, there are following stages: problem recognition, solutions designing, and their evaluation. The second one needs to be treated as a choice of one of possible solutions made by a decision-maker.

The problem recognition phase consists of defining the problem in a precise way and specifying the essence of the problem. On the basis of acquired data and data collected specifically for this purpose, the essence of the problem is defined, as well as its scope, intensity, time when it occurred or other period important for that matter, possibilities and limitations of the solution to the problem.

It also needs to be added that when a managerial task appears and has to be done, what needs to be taken into account is being aware of the need of solving a decision-making problem as well as making diagnosis and doing a situational analysis. Thus, decision making starts from setting a task; a particular cycle comes to an end when a task which is the beginning of the cycle comes to an end.

The need for a decision results from a problem which appears or a possibility to rationalize activities of an organization. A problem appears when the achieved results fail to meet the organization's aims. This means that some aspects of its work require improvement. Whereas a possibility means that decision-makers see abilities for an organization to improve its work or even exceed the set objective.

If a manager notices a problem or possibilities, it is necessary to realize what the specificity of a situation is. The stage of decision making, in which decision-makers analyse elementary causal link in a particular situation, is called diagnostics or evaluation.

Its main role is to examine the external and internal environment in order to acquire information, which is essential to generate a set of alternative solutions, which - as presented at a particular stage of decision making - may lead to the end of a particular task and achievement of particular aims. 
Limitations are the conditions to achieve aims of an organization defined by the external environment and human resources of an organization. The basic limitations are the law and normative acts, deficiency of funds, low competence of staff, technological and innovative needs and limited qualifications of subordinate managers for making managerial decisions.

Criteria for making decisions are standards according to which it is necessary to look for alternatives.

The next step is to compare and evaluate given variants of activities with the use of appropriate methods and criteria (Wiśniewski et al., 2017).

The consequence of all these activities is the fact that a manager who makes a decision chooses an appropriate variant and this is what decision making exactly means. The best variant is the one which enables an organization to achieve a result that corresponds to its aims and values and uses the fewest resources.

This stage aims at establishing the facts and explaining them. Thus, it consists of two layers: descriptive and explanatory. In the description special emphasis is put on precise and accurate collection of information concerning the facts underlying the problem. Such information is of different value, not only because of veracity, but also because of quality and exactness of the information. In practice, there are many methods, techniques and technical directives which enable us to appropriately describe the facts signifying occurrence of a problem. However, the basic principle is the principle of objective truth, which can be used in different kinds of organizations. It may be generally defined as having all the facts. It is also necessary to assume that learning about the facts will be done in accordance with recommendations and principles of the current scientific knowledge available to a particular organization. These are of course model assumptions. The reality, however, often follows different rules, not necessarily scientific ones.

Real conditions are of significant importance as decision-makers design and make decisions in such conditions. According to crisis managers in Łódź voivodeship and their experience, such conditions are as follows:

- high indeterminacy and low situational predictability of the result,

- deficiency of information in case of decision making,

- strict time limits,

- high risk level,

- very stressogenic conditions of work,

- high responsibility for decision making, paying high prices for mistakes,

- strict limits concerning decision-maker's activities due to requirements connected with regulations and instructions,

- necessity for generating non-standard decisions in irregular, untypical decisions occurring in negative conditions of cooperation,

- necessity for teamwork and co-operation in conformity with many entities in case of life-threatening situations. 
Furthermore, these managers emphasize the fact that at the level of decision designing there are two kinds of difficulties, and their intensity depends on structuralizing of a problem to the solution. The first difficulty is the necessity to predict consequences of circumstances of future activities, which may influence their results. Sometimes the same activities may end up with achieving different results. The second difficulty is connected with defining influence of a decision-maker on the evaluation of predicted results and formulating the criteria of choice (WBiZK, 2019).

Another problem which can occur at the stage of designing is values scales used for evaluation of the predicted results. In case of problems, which are structuralized correctly, the predicted effects of activities are usually measurable and objective indicators can be used to evaluate them. However, in practice, decision-makers generally solve poorly structuralized problems, and among indicators measuring effectiveness of socio-economic systems there are so-called soft indicators, with no quantification and objectivization (Hubbard, 2013).

These managers admit that if there is no possibility to apply objectivized values scales, there is an option of replacing it with own preference scales (WBiZK, 2019). Therefore, in some decisions concerning choice of measures to achieve success, it is necessary to trust managers' values scales and beliefs. Thus, evaluation of crisis situation may vary significantly among decision-makers.

It needs to be added that scales values of a decision-maker and resulting preferences concerning aims and measures plays an important role during the process of criteria formulation. These criteria are crucial while making decision as their selection is a critical point in decision making process due to the fact that they determine the shape of a decision.

The aim of decision making stages is to sort variants of solutions by their usefulness due to the set criteria. The review of each variant needs to include the process of outcome prediction and this is a crucial element as this assessment is supposed to lead to a particular choice decision.

Sometimes all variants seem to be equally good. In order to make choice, a decision maker needs to collect appropriate information describing every alternative. It is obligatory to follow the rule that particular variants are contrasted with criteria, not with other alternatives. A decision-maker needs to avoid acceding to one correct variant only. Such an unfortunate case may happen when decision-makers compare alternatives and in this way they lose sight of aims and final decision making results.

It needs to be pointed out that particular stages and elements of the decision-making process are not always consecutive. For example, at the designing level there can be new problems to solve, which may require taking a step back to the recognition level. Sub cycles may also appear in repetitive cycles of the whole process. Moreover, there can be many cycles next to each other concerning different decisions, but each of them can be at a different level at a particular moment. 
It needs to be emphasized that a decision is made if it is carried out by an executive subsystem of a crisis management system. When the process of its implementation starts, the decision moves from the abstractive conclusions plane to the reality plane. At a stage of decision development, crisis managers need managerial and administrative skills as well as power of persuasion. The process of decision execution reminds the process of introducing a strategy and its success is attributed to effectiveness of management and transforming managerial ideas to practical activities. No consequence of a decision in action is only another variant of problem solving.

After executing a decision in practice and finishing the whole work cycle connected with a particular crisis situation, crisis managers from Łódź crisis management department carry out an analysis of both stages, decision-making and implementation of the decision. These analyses are conducted in crisis management departments, which take part in the problem of crisis solving. In these works all records connected with the decision-making process are used. If crisis management takes a longer time, discussions and meetings of crisis managerial staff take place, and these are recorded as well. Thus, important elements of these analyses are notes and records of interviews with decision-makers who take part in those meetings. The aim of these analyses is evaluation of the effects of performed crisis management and making conclusions in order to improve the decision-making process and practical work of the executive system. This evaluation is carried out by Crisis Management Department in Łódź, which draws up conclusions and recommendations that are passed to all crisis management departments and used systematically in trainings for crisis managers in Łódź voivodeship (WBiZK, 2019).

\section{References}

1. Balcerowicz, B. (2008). Słownik terminów z zakresu bezpieczeństwa narodowego. Warszawa, pp. 179.

2. Chyliński, A. (2015). Podglądanie ryzyka. Dyktat założén. Warszawa: pp. 142.

3. Frankfort-Nachmias, Ch., Nachmias, D. (2001). Metody badawcze w naukach społecznych. Poznań: pp. 54.

4. Hubbard, D.W. (2013). Pomiar uniwersalny. Warszawa: pp. 269.

5. Koźmiński, A.K., Latusek-Jurczak, D. (2011). Rozwój teorii organizacji. Warszawa: pp. 42.

6. Landreth, H., Colander, D.C. (2005). Historia myśli ekonomicznej. Warszawa.

7. Pietrek, G. (2018). System zarzadzania kryzysowego. Diagnoza i kierunki doskonalenia. Warszawa: pp. 108-220. 
8. Sienkiewicz-Małyjurek, K., Krynojewski, F.R. (2010). Zarzadzanie kryzysowe $w$ administracji publicznej. Warszawa: pp. 12-13.

9. Simon, H., March, J.G. (1964). Teoria organizacji. Warszawa.

10. Sobolewski, G. (2013). Ujęcie systemowe zarządzania kryzysowego w Polsce. Zarządzanie kryzysowe. Warszawa: pp. 10-27.

11. Sułkowski, Ł. (2012). Epistemologia i metodologia zarządzania. Warszawa: pp. 24.

12. Ustawa z dnia 26 kwietnia 2007 roku o zarzadzaniu kryzysowym. Dz.U. nr 89, poz. 590, z późn. zm.

13. Wiśniewski, B., Kozioł, J., Falecki, J. (2017). Podejmowanie decyzji w sytuacjach kryzysowych. Szczytno: pp. 78-83.

14. Wywiady osobowe i materiały pozyskane w Wydziale Bezpieczeństwa i Zarządzania Kryzysowego w Urzędzie Wojewódzkim w Łodzi (WBiZK) (2019). 